\title{
LANGUAGES AND CULTURES
}

Executive Council

\section{Chairman}

THE RT. HON. LORD LUGARD

\section{Members}

COLONEL DERENDINGER REV. FATHER H. DUBOIS MONSIEUR G. HARDY PROFESSOR DE JONGHE PROFESSOR B. MALINOWSKI DR. J. H. OLDHAM
SIR E. DENISON ROSS

PROFESSOR C. CONTI ROSSINI PROFESSOR RYCKMANS REV. FATHER SCHMIDT PROFESSOR SELIGMAN REV. E. W. SMITH

PROFESSOR R. THURNWALD

Directors

PROFESSOR H. LABOURET PROFESSOR DR. D. WESTERMANN

Administrative Director

DR. J. H. OLDHAM

Secretary-General

MR. HANNS VISCHER

Secretary

MISS D. G. BRACKETT

Hon. Treasurer

MAJOR SIR HUMPHREY LEGGETT

Hon. Auditors

MESSRS. MANN, JUDD, GORDON \& CO.

Hon. Solicitors

MESSRS. LAWRENCE JONES \& CO.

Bankers

MESSRS. BARCLAYS BANK (DOMINION, COLONIAL \& OVERSEAS)

Central Office

22 CRAVEN STREET, LONDON, W.C. 2

Directors' Offices

26 RUE DE LA PÉPINIÈRE

PARIS, VIII
BERLINERSTRASSE 13 BERLIN-SÜDENDE

All business communications should be addressed to the Central Office in London 


\section{PUBLICATIONS ISSUED \\ UNDER THE AUSPICES OF THE \\ INTERNATIONAL INSTITUTE OF AFRICAN LANGUAGES AND CULTURES}

CHAKA. An Historical Romance by Thomas Mofolo. Translated from the original Sesuto by F. H. Dutton, with an introduction by Sir Henry Newbolt. Pp. xvi and $200 . \quad 75.6 d$. net.

NUER CUSTOMS AND FOLKLORE. By Ray Huffman, with preface by Diedrich Westermann, Professor of African Languages at the University of Berlin. Pp. viii and 107 , with 8 illustrations. $8 s .6 d$. net.

THE BAVENDA. By $H$. A. Stayt, with an introduction by Mrs. A. W. Hoernlé, Lecturer in Social Anthropology at the University of the Witwatersrand. $\mathrm{Pp}$. xvi and 400 , with 48 illustrations and a map.

3os. net.

TALES TOLD IN TOGOLAND. By $A . W$. Cardinall, author of Natives of the Northern Territories of the Gold Coast, A Gold Coast Library, In Ashanti and Beyond. With a chapter on the mythical and traditional history of Dagomba by E. F. Tamakloe. Pp. viii and 279. IGs. net.

IN THE PRESS

ECONOMICS IN PRIMITIVE SOCIETY. By Richard Thurnwald, Professor of Ethnology, Psychology and Sociology at the University of Berlin.

About 25s, net.

Special discount to members of the Institute on application to the Secretary.

RECENT ADDITIONS TO THE SERIES OF MEMORANDA ISSUED IN CONNEXION WITH 'AFRICA'

No. 8. The Missionary and Anthropological Research, by $D$. Westermann and R. Thurnwald; price $\mathrm{I} s$.

No. 9. A Five-Year Plan of Research; price is.

Orders for any of the above publications may be sent either through any bookseller or direct to the office of the Institute.

Printed in Great Britain at the University Press, Oxford, by John Johnson, Printer to the University 